\title{
Redesain Terminal Pelabuhan Tanjung Emas Dengan Pendekatan ARSiteKtur Ekologis Di SEMARANG
}

\author{
Yoyok Ariyono, Musyawaroh, Sri Yuliani \\ Program Studi Arsitektur \\ Jurusan Arsitektur Fakultas Teknik \\ Universitas Sebelas Maret Surakarta \\ Email: yoyok.arsitektur@gmail.com
}

\begin{abstract}
Port of Tanjung Emas Semarang is important role as a gateway to the sea for the economy and tourism, especially in Central Java. In the decision the directors of PT. Pelabuhan Indonesia III August 5, 2002 mentions the development plan Tanjung Emas Port in Semarang and plan to build a passenger terminal building of ships. Port of Tanjung Emas Semarang also included in the program of Eco-Port so that the development process must consider environmental aspects. Redesign of the passenger ship terminal at the Port of Tanjung Emas Semarang is aimed to increase user comfort and to change the dirty and polluting image of the port terminals. The main problem of this design is how toimprove the conditions terminals to make it better and environmentally sound by applying the principles of Ecological Architecture. The method is based on the concept of Ecology Architecture with the cozy atmosphere is created by the climate-responsive design and environmentally friendly. The result of redesign is passenger ship terminal at the Port of Tanjung Emas Semarang with appropriate Ecological Architecture concept that can be convenient for the visitors and the building can maintain harmony between architecture and surrounding environment.
\end{abstract}

Keywords: Building Ecofriendly, Ecology Architecture, Passenger Ship Terminal, Redesigning

\section{PENDAHULUAN}

Sarana dan prasarana transportasi laut memegang peranan penting dalam membuka akses dan menghubungkan wilayah antar pulau serta merupakan suatu sarana yang berkorelasi positif terhadap pertumbuhan ekonomi dan mempengaruhi hampir semua aspek kehidupan, baik dalam integritas nasional maupun internasional (Triadmodjo, 1996).

Pelabuhan Tanjung Emas Semarang merupakan pelabuhan Kelas I/berskala internasional. Pelabuhan ini mempunyai kedudukan yang strategis sebagai pendukung transportasi laut bentangan timur, barat dan utara. Ditinjau dari segi fungsi Pelabuhan Tanjung Emas merupakan sebuah pelabuhan campuran yang digunakan sebagai pelabuhan penumpang, barang serta minyak, oleh karena itu pelabuhan memiliki pendapatan yang tidak sedikit dan berpotensi untuk selalu berkembang sebagaimana termuat dalam masterplan yang ditetapkan oleh Keputusan Direksi PT. (PERSERO) Pelabuhan Indonesia III Nomor Kep.24/Pj.3.02/P.III-2002 tanggal 5 Agustus 2002: Tentang Pengembangn Pelabuhan Tanjung Emas Semarang.
Pelabuhan Tanjung Emas Semarang masuk dalam program Eco-Port/bandar indah sesuai keputusan PT Pelabuhan Indonesia III: Pelabuhan Tanjung Emas Berwawasan Lingkungan tahun 2002. Program tersebut bertujuan untuk mengatasi masalah lingkungan pelabuhan yang penting untuk segera ditangani, yakni: kesehatan dan keselamatan kerja, pengelolaan limbah, pengerukan, mutu air, kebisingan, pencemaran, polusi, kualitas udara, kerusakan habitat, dan pemakaian energi.

Di dalam Pelabuhan Tanjung Emas Semarang terdapat sebuah fasilitas pokok berupa gedung terminal penumpang kapal laut yang khusus untuk memfasilitasi perpindahan penumpang, bagasi/barang serta kendaraan baik pelayaran nasional maupun internasional dan melayani penumpang selama 24 jam termasuk hari libur. Terminal ini juga sering disinggahi oleh berbagai jenis kapal pesiar mancanegara. Dalam masterplan di atas juga menyebutkan rencana pembangunan terminal penumpang seluas 2,1 ha dengan back up area 5-10 ha untuk keperluan pengembangan serta fasilitas penunjang 
seperti restoran, servis, dan lain-lain dengan besar anggaran 100 miliyar.

Gedung terminal penumpang kapal laut di Pelabuhan Tanjung Emas Semarang saat ini kurang optimal dalam memfasilitasi kegiatan dari para pengguna karena bangunan merupakan hasil alih fungsi atau renovasi dari gudang barang yang dahulu tidak direncanakan secara khusus sebagai gedung terminal, beberapa permasalahan yang ada saat ini di antaranya:

1. penampilan fisik bangunan masih menyerupai gudang/tidak representatif;

2. kapasitas besaran ruang tidak mencukupi;

3. pembagian ruang dan sirkulasi yang masih belum jelas;

4. masalah banjir rob;

5. minimnya area hijau;

6. pengelolaan limbah bangunan yang buruk mengakibatkan pencemaran air laut dan kelangkaan sumber air bersih/tawar;

7. tidak optimalnya pencahayaan dan penghawaan alami dalam ruang;

8. tingginya konsumsi pemakaian energi. Berdasarkan poin-poin di atas maka permasalahannya adalah "Bagaimana Konsep Redesain Terminal Penumpang Kapal Laut di Pelabuhan Tanjung Emas Semarang dengan Pendekatan Arsitektur Ekologis"

\section{METODE}

Untuk mendapatkan desain akhir berupa Terminal Penumpang Kapal Laut di Pelabuhan Tanjung Emas Semarang yang ramah lingkungan, metode digunakan mengacu pada konsep Arsitektur Ekologis yang diaplikasikan pada tiga point, di antaranya:

1. Sirkulasi

Arsitektur Ekologis yang diterapkan pada sirkulasi adalah melalui kemudahan dan kenyamanan. Sirkulasi di luar bangunan berupa skywalk dengan tujuan konservasi tanah dan efisiensi lahan melalui sistem parkir vertikal. Sirkulasi di dalam bangunan memberi kejelasanan dan kenyamanan dengan cara memisahkan jalur sirkulasi berdasarkan pelaku dan tujuan kegiatannya.
2. Bangunan

Arsitektur Ekologis yang diterapkan pada bangunan adalah konsep bangunan yang responsif terhadap iklim dan masalah banjir rob melalui perencanaan bentuk massa aero dinamis dengan konstruksi bangunan panggung.

3. Utilitas Bangunan

Arsitektur Ekologis yang diterapkan pada utilitas bangunan adalah melalui sistem penyediaan air bersih yang ramah lingkungan, sistem pengolahan air kotor dan limbah yang tidak mencemari lingkungan serta sistem penyediaan listrik dari sumber energi alternatif.

\section{ANALISIS}

\subsection{Analisis Peruangan}

Analisis kebutuhan ruang bertujuan untuk mengetahui jenis-jenis ruangan yang dibutuhkan oleh terminal. Ruanganruangan ini diperoleh dari pelaku dan kegiatan manusia maupun kendaraan di dalam terminal (lihat Tabel 1).

Tabel 1. Kebutuhan Ruang

\begin{tabular}{lll}
\hline Pelaku & Kegiatan & Peruangan \\
\hline Penumpang & Datang & Hall \\
& Membeli tiket & Penjualan tiket \\
& Memeriksa & Pemeriksaaan \\
& tiket dan & tiket, $x$-ray dan \\
& kesehatan & karantina \\
& Menunggu & Ruang tunggu \\
& keberangkatan & \\
& Menitipkan & Pemeriksaaan \\
& bagasi & bagasi \\
Penumpang & Bongkar muat & Loading dock \\
membawa & ke dalam & Dermaga \\
kendaraan & kapal & \\
Pengantar, & Menunggu & Ruang tunggu \\
Penjemput & penumpang & \\
Pengelola & Bekerja & Kantor \\
& & pengelola \\
Semua & Menitipkan & Parkir \\
Pelaku & kendaraan & kendaraan \\
& Ibadah & Mushola \\
& Makan & Kafetaria \\
& MCK & Toilet \\
Pedagang & Berjualan & Kios \\
\hline
\end{tabular}




\subsection{Analisis Tapak}

Tapak berada di lokasi terminal penumpang kapal laut (TPKL) saat ini yaitu di Jalan Coaster No.10 Pelabuhan Tanjung Emas Semarang. Berdasarkan masterplan yang ditetapkan oleh PT. Pelindo III, 2002 luas tapak disediakan $\pm 2,1$ ha dengan area pengembangan 5-10 ha. Kedalaman kolam pelabuhan saat ini - 8m. Lokasi tapak strategis karena dekat dengan pusat kota, fasilitas umum serta prasarana transportasi lain. Memiliki utilitas dan infrastruktur yang memadai.

Orientasi tapak terekspose dari jalur regional Jakarta-Surabaya. Luasan tapak dapat menampung seluruh kebutuhan ruang yang direncanakan.

\subsection{Analisis Pencapaian}

Analisis pencapaian bertujuan untuk menentukan Main Entrance (ME) dan Side Entrance (SE) yang ideal.

Satu-satunya akses pencapaian kendaraan pengunjung menuju lokasi tapak adalah melalui Jalan Coaster Komplek Pelabuhan Tanjung Emas Semarang oleh karena itu letak ME dan SE direncanakan menghadap ke sisi timur atau searah jalan kedatangan pengunjung tersebut.

Letak pintu masuk dan keluar baik ME maupun SE direncanakan sejauh mungkin dari titik-titik kepadatan guna meminimalisir terjadinya kemacetan (lihat Gambar 1).

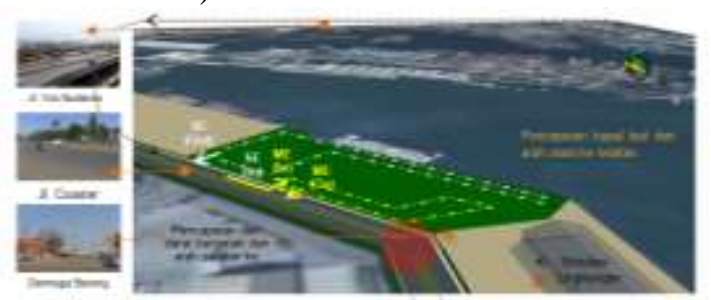

Gambar 1. Analisis Pencapaian

\subsection{Analisis Sirkulasi}

Bertujuan untuk mengatur jalannya sirkulasi di dalam tapak dan bangunan yang memberi kemudahan serta kenyamanan bagi pengguna terminal.

Sirkulasi kendaraan di dalam tapak diminimalisir dengan menerapkan sistem pencapaian langsung menuju ke area parkir pada masing-masing fasilitas. Memisahkan sirkulasi antara manusia, barang dan kendaraan.
Konservasi tanah dan efisiensi lahan melalui sistem parkir vertical dan skywalk (lihat Gambar 2).

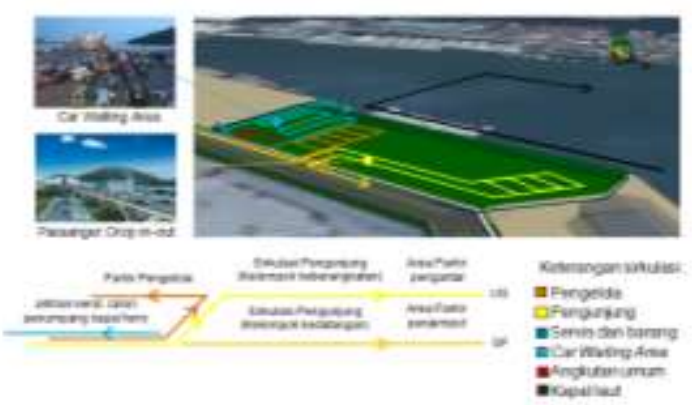

Gambar 2. Sirkulasi Di Dalam Tapak

Sirkulasi di dalam bangunan menggunakan model sirkulasi memusat pada hall untuk memudahkan dalam pencapaian dan pengawasan. Memisahkan antara kegiatan keberangkatan dan kedatangan, antara sirkulasi penumpang mancanegara dan domestik serta sirkulasi pengelola dengan pengunjung (lihat Gambar 3).

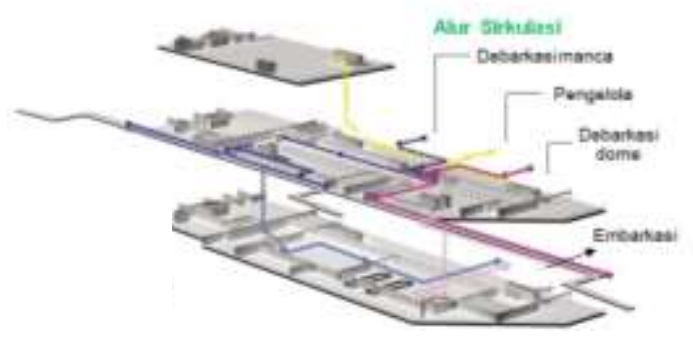

Gambar 3. Sirkulasi Di Dalam Bangunan

\subsection{Analisis Klimatologi}

Angin di Indonesia termasuk di Pelabuhan Tanjung Emas Semarang ratarata berhembus dari tenggara ke barat laut dan sebaliknya sehingga bangunan yang dapat merespon angin dengan baik adalah bangunan yang memanjang dari arah tenggara ke barat laut agar dapat mengurangi tekanan angin.

Angin darat bergerak di siang hari dari selatan ke utara semakin kencang sedangkan angin laut bergerak di malam hari dari utara ke selatan semakin lemah. Arah angin masih dapat dibelokkan (Lippsmeier, 1994), maka angin kencang dibelokkan dengan sudut bangunan sedangkan angin yang membawa debu dinetralisir menggunakan pepohonan. 
Mengacu pada pendapat Karyono (2010), "Pengurangan radiasi matahari pada bangunan dapat dilakukan dengan menciptakan 'pembayangan' melalui pohon besar di sekitar bangunan. Jika perolehan panas matahari dapat diminimalkan, maka suhu udara di dalam bangunan akan rendah".

Berdasarkan analisis angin dan matahari, orientasi bangunan menghadap utaraselatan untuk mendapatkan pencahayaan penghawaan alami yang baik (lihat Gambar 4).

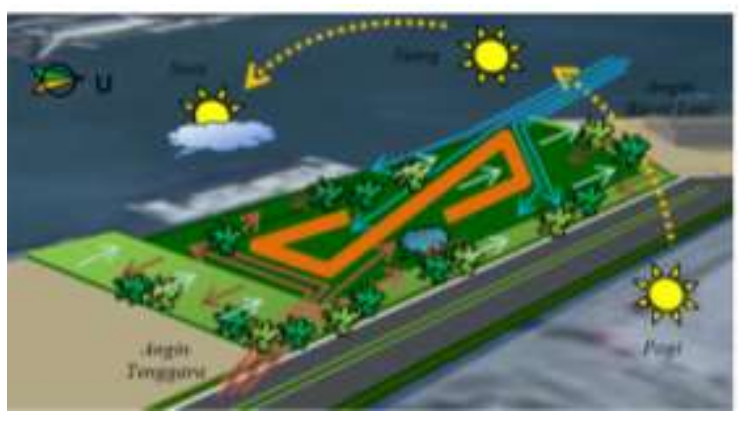

Gambar 4. Analisis Klimatologis

\subsection{Analisis Pemintakatan (Zoning)}

Pemintakatan bertujuan untuk mengelompokkan ruang berdasarkan sifat kegiatan dan tuntutan ruang (lihat Tabel 2).

Tabel 2. Pemintakatan

\begin{tabular}{|c|c|c|}
\hline $\begin{array}{l}\text { Kelompok } \\
\text { Ruang }\end{array}$ & Ruang & Tuntutan \\
\hline Publik & $\begin{array}{l}\text { - Semua } \\
\text { ruang } \\
\text { kegiatan } \\
\text { utama: area } \\
\text { kedatangan, } \\
\text { area } \\
\text { keberangkat } \\
\text { an, ruang } \\
\text { tunggu, } \\
\text { ruang } \\
\text { informasi, } \\
\text { agen tiket, } \\
\text { dan lain- } \\
\text { lain }\end{array}$ & $\begin{array}{l}\text { - Mudah } \\
\text { dijangkau } \\
\text { - Dekat dengan } \\
\text { pencapaian } \\
\text { utama (ME) } \\
\text { - Mendapat } \\
\text { pencahayaan dan } \\
\text { penghawaan } \\
\text { alami yang baik } \\
\text { - Sudut pandang } \\
\text { kedalam menjadi } \\
\text { pertimbangan } \\
\text { utama }\end{array}$ \\
\hline Prifat & $\begin{array}{l}\text { Kantor } \\
\text { Pengelola }\end{array}$ & $\begin{array}{l}\text { - Dekat dengan SE } \\
\text { - Publik dapat } \\
\text { menjangkau }\end{array}$ \\
\hline
\end{tabular}

\begin{tabular}{lll}
\hline & & dengan \\
& persyaratan \\
& tertentu \\
& - Mendapatkan \\
& pencahayaan dan \\
& penghawaan \\
& alami yang baik \\
& & - Sudut pandang \\
& & keluar menjadi \\
& & pertimbangan \\
& & Dapat dijangkau \\
& & dengan mudah \\
& - Parkir & dari area publik \\
& kendaraan & Mendapatkan \\
& - Kafetaria & pencahayaan dan \\
& - Kios & penghawaan \\
& & yang baik \\
\hline
\end{tabular}

3.7 Konsep Penanggulangan Banjir (rob) Bertujuan untuk mengatasi permasalahan banjir rob pada tapak setinggi $30-80 \mathrm{~cm}$. Sistem penanggulangan banjir rob yang direncanakan di antaranya:

1. Melakukan pelebaran dan memperdalam selokan lingkungan serta menjaga kebersihannya;

2. Meninggikan permukaan tapak setinggi $1,5 \mathrm{~m}$ dengan konstruksi panggung. Ruang antara permukaan tapak asli/dahulu dengan permukaan tapak sekarang/setelah dipanggung dapat dimanfaatkan sebagai ruang penampungan air pada musim kemarau dan konservasi habitat biota laut;

3. Memperluas area resapan air melalui green roof;

4. Mengolah air di dalam tapak melalui proses desalinasi (lihat Gambar 5).

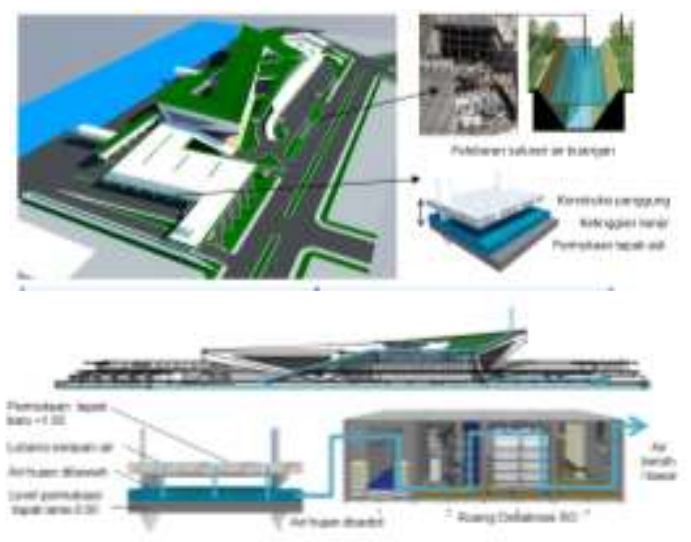

Gambar 5. Analisis Penanggulangan Banjir 


\subsection{Analisis Utilitas Bangunan}

Bertujuan menentukan sistem utilitas yang efektif dan ramah lingkungan.

1. Sistem Air Bersih

Saat ini pada lokasi tapak terdapat permasalahan keterbatasan sumber air bersih/tawar. Sebagai upaya perwujudan bangunan berwawasan lingkungan maka dalam mencukupi kebutuhan air bersihnya selain mengandalkan suplai air dari PDAM juga akan menerapkan sistem desalinasi air laut dan memanfaatan air hujan melalui proses watertreatment. Potensi air laut yang melimpah sepanjang tahun dimanfaatkan sebagai sumber air bersih melalui sistem desalinasi air laut. Sumber air laut disaring pada bak pengendap awal kemudian untuk menghilangkan kadar asin dan bakteri/senyawa berbahaya air tersebut dipanaskan dan dipompakan melalui pipa pemanas ke tanki desalinasi dan selanjutnya dipompakan lagi ke tanki air atas. Air bersih hasil olahan tersebut siap untuk didistribusikan ke dalam ruang-ruang yang memerlukan melalui sistem down feed distribution (lihat Lampiran 1).

2. Sistem Pengolahan Air Kotor

Sistem pembuangan air kotor dan limbah (tinja) pada terminal akan menerapkan upaya konservasi yaitu dengan cara memanfaatan kembali air yang telah dipergunakan melalui proses watertreatment, meminimalisir pembuangan limbah ke luar dan berusaha tidak merusak sirklus air laut. Air buangan yang berasal dari floor drain dan air dari dapur yang berupa grey water diolah dengan sistem watertreatment pada biofil (alat yang mengubah air kotor menjadi air bersih). Air yang telah diolah kemudian ditampung pada tangki khusus sehingga nantinya air dapat digunakan kembali untuk keperluan menyiram kloset dan sistem pemadam kebakaran. Limbah (tinja) dialirkan dan diolah pada sapitank biofil yang terbuat dari bahan kedap air. Penempatannya di atas batas ketinggian banjir rob. Endapan hasil pengolahan dapat dijadikan pupuk tanaman (lihat Lampiran 1).

3. Penyediaan Sumber Energi Listrik

Sumber utama energi listrik dipasok dari jaringan kota (PLN). Untuk kebutuhan darurat tersedia dua buah generator/genset. Selain dua sumber energi tersebut diupayakan pula pengumpulan sumber energi alternatif melalui energi panas sisa pembakaran yang diperoleh dari ruang inceneratorl pembakar sampah dan uap panas proses desalinasi air laut (lihat Lampiran 1).

\section{KESIMPULAN (KONSEP DESAIN)}

Dari hasil analisa serta hasil korelasi dari beberapa data di atas maka diperoleh hasil berupa:

Nama

: Terminal Penumpang

Kapal Laut

Lokasi

$$
\text { : Jl. Coaster No.10 }
$$

Komplek Pelabuhan

Tanjung Emas, Semarang.

Luas Lahan $\quad: 21.000 \mathrm{~m}^{2}$

Luas Bangunan : $16.000 \mathrm{~m}^{2}$

Konsep Arsitektur Ekologis yang diterapkan pada tapak dan bangunan Terminal Penumpang Kapal Laut di Pelabuhan Tanjung Emas Semarang, antara lain:

1. Lebar bangunan antara 14-20 meter memungkinkan cahaya dan udara dari luar dapat masuk ke seluruh ruangan.

2. Tata massa bangunan yang aero dinamis sebagai repon terhadap kondisi iklim pesisir (lihat Gambar 6).

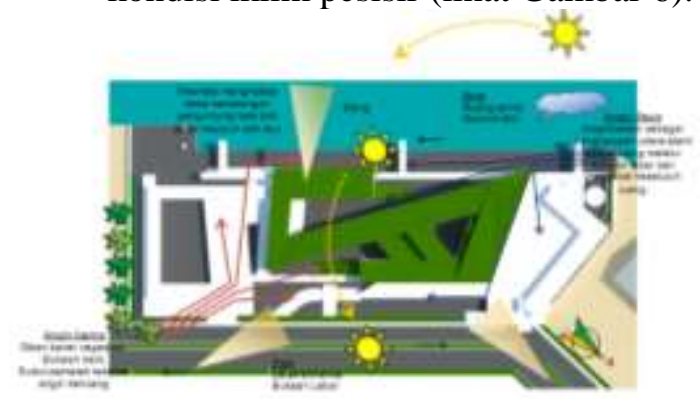

Gambar 6. Respon Klimatologis Bangunan 
3. Mengatur jarak dan ketinggian antar massa bangunan untuk memaksimalkan potensi alami (matahari, angin dan lingkungan) ke dalam bangunan.

4. Konstruksi bangunan panggung sebagai respon terhadap permasalahan banjir rob dan meminimalisir kelembaban (lihat Gambar 7).

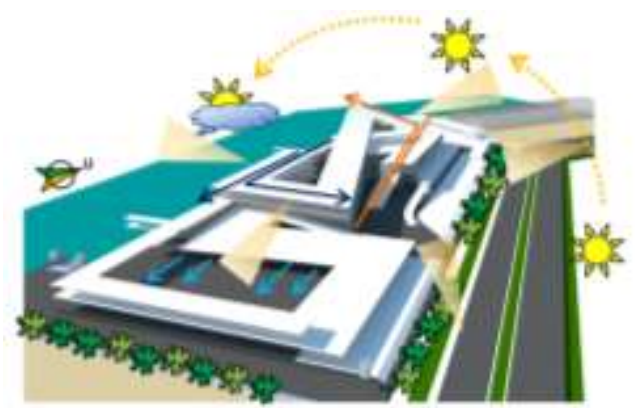

Gambar 7. Bentuk Aero Dinamis Bangunan

5. Konservasi tanah dan efisiensi lahan melalui sistem parkir vertikal dan skywalk.

6. Ruang Terbuka Hijau (RTH) sebesar $25 \%$ dari luas lahan untuk memperbaiki kondisi udara di lingkungan terminal.

7. Meminimalisir luasan massa bangunan dan menggantikan area resapan yang terbangun dengan menerapkan green roof untuk memaksimalkan green space sebagai area resapan (lihat Gambar 8).

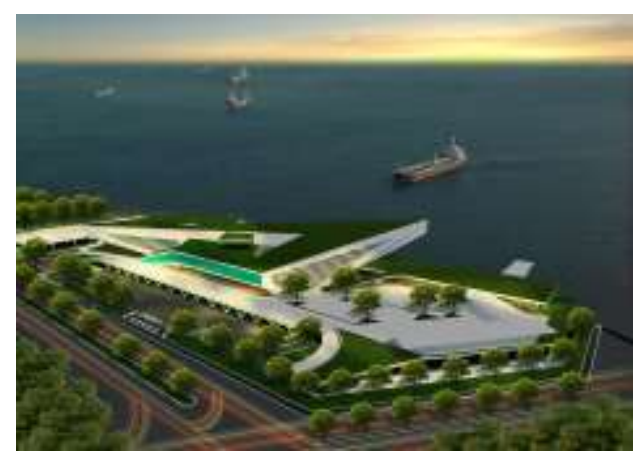

Gambar 8. Green Roof pada Atap Bangunan

8. Penggunaan dinding kaca dengan secondary skin untuk mengurangi efek panas yang ditimbulkan oleh cahaya matahari.
9. Atap dengan kemiringan yang cukup untuk mengalirkan air hujan dengan cepat dan tritisan panjang agar air hujan tidak tampias (lihat Gambar 9).

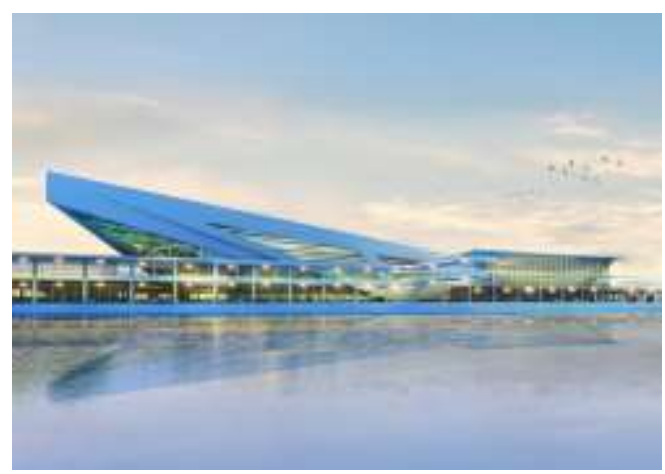

Gambar 9. Secondary Skin Terminal

10. Konservasi air bersih dilakukan dengan menerapkan sistem pemurnian/desalinasi air laut dan pengolahan air yang telah digunakan melalui proses watertreatment.

11. Penghematan energi dengan cara memanfaatkan energi panas yang dihasilkan dari sisa pembakaran limbah pada ruang incenerator dan uap panas hasil dari proses desalinasi yang diolah menjadi sumber energi listrik alternatif (lihat Lampiran1).

\section{REFERENSI}

Karyono, Tri Harso, 2010. Pengantar Pemahaman Arsitektur Hijau di Indonesia. Rajawali Pers.

Lippsmeier, Georg, 1994. Bangunan Tropis. Jakarta: Erlangga.

Masterplan PT.(PERSERO) Pelabuhan Indonesia III Nomor Kep.24/Pj.3.02/ P.III-2002 tanggal 5 Agustus 2002. Tentang Pengembangn Pelabuhan Tanjung Emas. Semarang: (Draf Final Raport)

Triadmodjo, Bambang, 1996. Perencanaan Pelabuhan. Yogyakarta: Beta offset. 


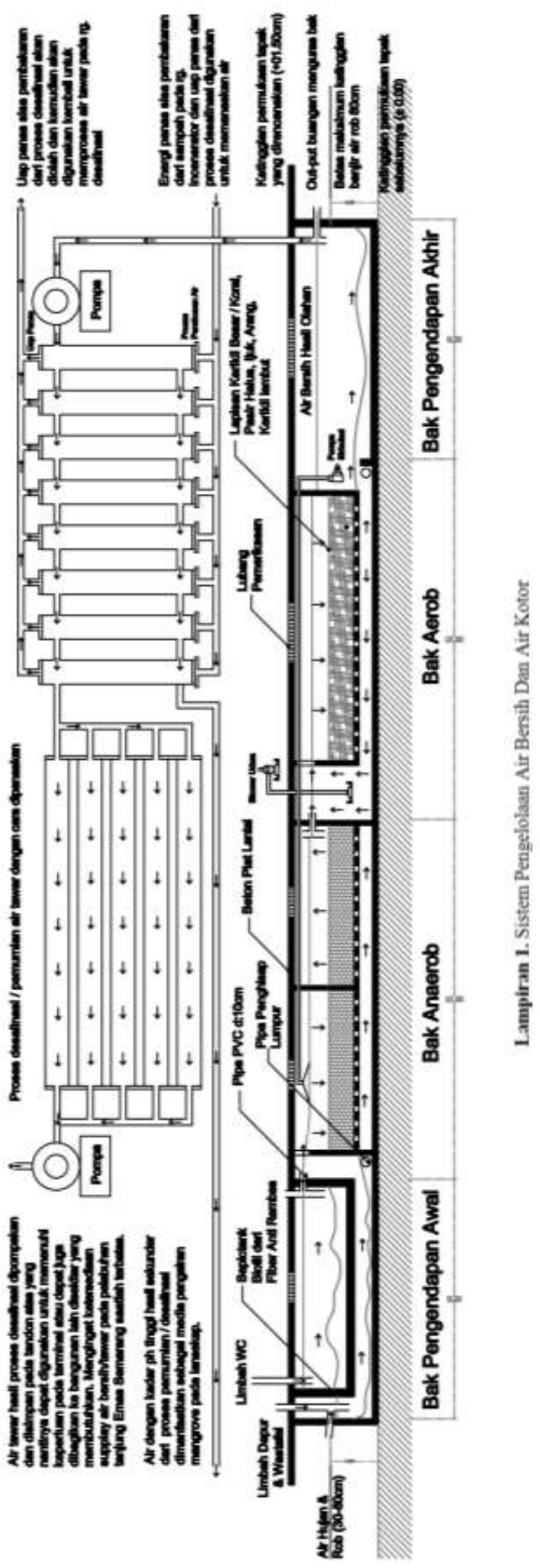

